\section{Case Report}

A 34-year-old lady presented with a 3 year history of central weight gain, hypertension and secondary amenorrhoea.

On examination, she was obese with a BMI of $33 \mathrm{~kg} / \mathrm{m}^{2}$ with a buffalo hump. There was evidence of generalised muscle weakness, mild hirsutism and violaceous striae over the abdomen.

Initial 24-hour urinary free cortisol (UFC) was raised (536 nmol/24hr) and subsequent overnight dexamethasone suppression test (DST) was elevated at $593 \mathrm{nmol} / \mathrm{L}$.

Low and high dose DST confirmed the diagnosis of ACTH-independent Cushing's syndrome with an unusual trend of increasing plasma cortisol levels compared with baseline. Adrenal imaging revealed 4 right adrenal nodules $(7-11 \mathrm{~mm}$ in size) and a normal left adrenal.

\section{CT Report:}

Right Adrenal: 4 nodules; $2 \mathrm{x}$ $7 \mathrm{~mm}, 9 \mathrm{~mm}$ and $10 \mathrm{~mm}$ respectively

Left Adrenal: Normal

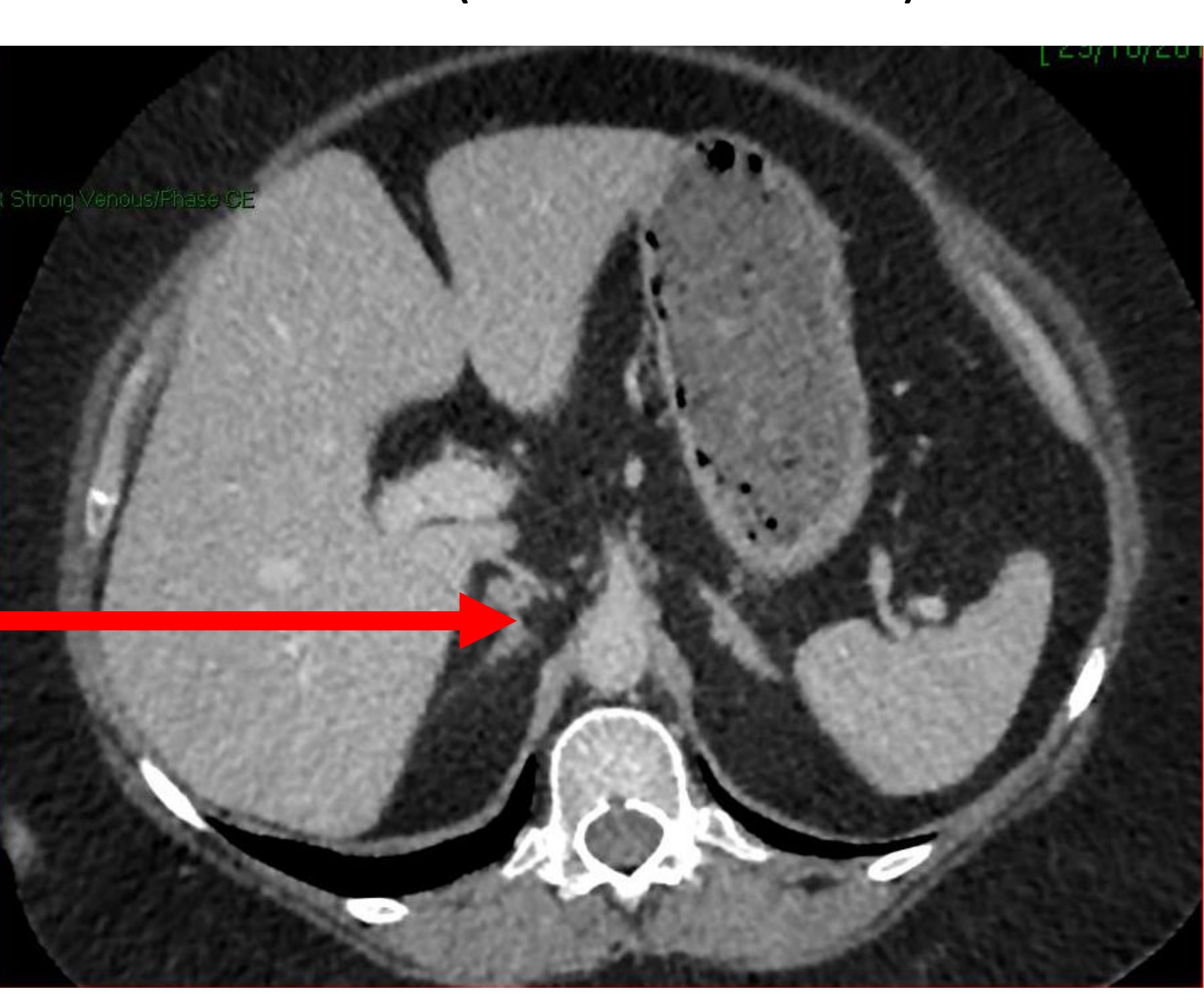

\section{Initial Investigations}

\begin{tabular}{|c|c|c|c|}
\hline Investigation & Day & Value & Reference Range \\
\hline $\begin{array}{c}\text { Dexamethasone } \\
\text { 0.5mg QDS } \\
\text { ACTH } \\
\text { Cortisol } \\
\text { UFC }\end{array}$ & Day 0 & $\begin{array}{l}<10 \\
441\end{array}$ & $\begin{array}{c}7-51 \mathrm{ng} / \mathrm{L} \\
<50 \mathrm{nmol} / \mathrm{L} \\
<100 \mathrm{nmol} / 24 \mathrm{hrs}\end{array}$ \\
\hline $\begin{array}{l}\text { ACTH } \\
\text { Cortisol } \\
\text { UFC }\end{array}$ & Day 1 & $\begin{array}{l}408 \\
212\end{array}$ & $\begin{array}{c}<50 \mathrm{nmol} / \mathrm{L} \\
<100 \mathrm{nmol} / 24 \mathrm{hrs}\end{array}$ \\
\hline $\begin{array}{l}\text { ACTH } \\
\text { Cortisol } \\
\text { UFC }\end{array}$ & Day 2 & $\begin{array}{l}<10 \\
445 \\
344\end{array}$ & $\begin{array}{c}7-51 \mathrm{ng} / \mathrm{L} \\
<50 \mathrm{nmol} / \mathrm{L} \\
<100 \mathrm{nmol} / 24 \mathrm{hrs}\end{array}$ \\
\hline $\begin{array}{c}\text { Dexamethasone } \\
\text { 2mg QDS } \\
\text { ACTH } \\
\text { Cortisol } \\
\text { UFC }\end{array}$ & Day 3 & $\begin{array}{l}444 \\
321\end{array}$ & $\begin{array}{c}<50 \mathrm{nmol} / \mathrm{L} \\
<100 \mathrm{nmol} / 24 \mathrm{hrs}\end{array}$ \\
\hline $\begin{array}{l}\text { ACTH } \\
\text { Cortisol } \\
\text { UFC }\end{array}$ & Day 4 & $\begin{array}{l}<10 \\
489 \\
346\end{array}$ & $\begin{array}{c}7-51 \mathrm{ng} / \mathrm{L} \\
<50 \mathrm{nmol} / \mathrm{L} \\
<100 \mathrm{nmol} / 24 \mathrm{hrs}\end{array}$ \\
\hline
\end{tabular}

\title{
Treatment and Subsequent Investigations
}

Metyrapone was used to normalise UFC pre-operatively and she underwent right adrenalectomy.

Post-operatively, cortisol levels remained elevated with an undetectable ACTH.

Pathological examination of the excised adrenal revealed characteristics of primary pigmented nodular adrenocortical disease (PPNAD), a rare familial cause of Cushing's syndrome.

\section{Discussion}

Primary Pigmented Nodular Adrenocortical Disease (PPNAD) is a form of micronodular adrenal hyperplasia causing ACTH-independent Cushing's syndrome. ${ }^{1}$ PPNAD may be isolated or appear as part of the Carney Complex, characterised by myxomas, skin hyperpigmentation and endocrine over-activity. ${ }^{2}$

Isolated PPNAD is an autosomal dominant inherited condition often associated with germline mutations in PRKAR1A and PDE. ${ }^{3}$ An important biochemical feature of PPNAD is a paradoxical rise in cortisol post high dose DST. This is thought to be mediated through a glucocorticoid receptor effect on the protein kinase A catalytic pathway. ${ }^{4}$

Bilateral adrenalectomy is the treatment of choice. Diagnosis of this rare condition can be challenging as imaging may not always identify the bilateral micronodular changes.

This case represents an extremely unusual cause of Cushing's syndrome ( $<1 \%$ of all cases) and highlights the importance of considering rare diagnoses before referring for surgery

\begin{tabular}{|c|ccc|}
\hline Investigations & Time & Value & Reference Range \\
\hline $\begin{array}{c}\text { Cortisol } \\
\text { (Post-operative) }\end{array}$ & 0800 & 336 & $\mathrm{nmol} / \mathrm{L}$ \\
& 0800 & 269 & $\mathrm{nmol} / \mathrm{L}$ \\
$\mathrm{nmol} / \mathrm{L}$
\end{tabular}

\section{Further Management}

Since adrenalectomy, this patient has lost 2-3kg of weight, blood pressure has normalised and the buffalo hump has disappeared. There were no other features of Carney complex observed in this patient. The original CT scan was re-assessed and two further nodules were noted retrospectively in the left adrenal.

Subsequent investigations revealed ongoing suppressed ACTH and raised midnight salivary cortisol at $3.6 \mathrm{nmol} / \mathrm{L}$. After overnight DST, plasma cortisol remains raised at $221 \mathrm{nmol} / \mathrm{L}$. Left adrenalectomy is now planned.

Subsequent investigation of her mother (who complained of a 10-year history of weight gain and uncontrolled hypertension despite 3 agents) also confirmed ACTH-independent Cushing's syndrome with an increase in UFC following high dose DST.

Genetic testing of these patients has failed to reveal the causative mutation thus far, although further testing of alternative candidates (e.g. PRKACA) is in progress.

1. Shenoy BV, Carpenter PC, Carney JA. Bilateral primary pigmented nodular adrenocortical disease: a rare cause of the Cushing syndrome. Am J Surg Pathol. 1984;8:335-344

2. Carney JA, Gordon H, Carpenter PC et al. The complex of myxomas, spotty pigmentation and endocrine overactivity. Medicine (Baltimore). 1985;64:270-283

. Libe R, Bertherat J. Molecular genetics of adrenocortical tumours, from familial to sporadic diseases. Eur J Endo. 2005;153:477-487

kinase A catalytic subunits. J Clin Endocrinol Metab. 2009;94:2406-2413 